\title{
ANALISIS KADAR GLUKOSA DARAH PADA PEKERJA SHIFT PAGI DAN SHIFT MALAM DI SIDOARJO
}

\author{
Yulia Indah Wulandari ${ }^{1}$, Mulyono ${ }^{2}$ \\ ${ }^{1,2}$ Departemen Keselamatan dan Kesehatan Kerja, Fakultas Kesehatan Masyarakat, Universitas \\ Airlangga \\ yuliawulandari.23@gmail.com
}

\begin{abstract}
Shift work besides has several advantages also has the negative effects which one is the physiological effects such as blood glucose metabolism disorders related with adrenal hormones (epinephrine) which is caused by circadian rhythm disturbance. The hormones can stimulate the heartbeat pace that increased blood glucose levels, which when produced excessively can lead to the diabetes. This study was conducted in PT. X at September 2015 aims to learns the pattern of PT. X shift working systems and analyze the random blood glucose levels on morning and night shift workers and also determine the efforts to control the effects of shift work at PT.X. This was a descriptive cross sectional research. Sample in this study were using the total population of shift workers in Rolling mill production unit who measured their random blood glucose levels while working on morning and night shift and was not suffering from diabetes mellitus or hypertension with total 26 respondents. The result showed that PT. X was applied weekly slow rotation and backward rotation pattern (night - daymorning) of shift working system. The difference random blood glucose levels of the most respondents showed a higher levels while working on the night shift than morning shift. Based on the research, PT. $X$ should apply a quick and forward rotation pattern (morning - day - night) of shift working system and giving 24 hours time rest at the end of night shift schedule and they should held the routine exercise activity once a week at the plant.
\end{abstract}

Keywords: random blood glucose, shift work

\begin{abstract}
ABSTRAK
Shift kerja selain memiliki beberapa keuntungan juga memiliki dampak negatif salah satunya yaitu dampak fisiologis berupa gangguan metabolisme glukosa darah yang berhubungan dengan hormon adrenalin (epinefrin) akibat gangguan irama sirkadian. Hormon ini dapat memacu laju dan kekuatan denyut jantung sehingga meningkatkan kadar glukosa darah, yang jika diproduksi berlebihan mengakibatkan timbulnya diabetes. Penelitian ini dilakukan di PT. X pada bulan September 2015, bertujuan mempelajari pola shift kerja dan menganalisis kadar glukosa darah pada pekerja shift pagi dan malam serta menentukan upaya pengendalian efek yang ditimbulkan oleh shift kerja di PT. X. Penelitian ini merupakan penelitian deskriptif cross sectional. Sampel dalam penelitian ini menggunakan total populasi pekerja shift di unit produksi Rolling mill yang diukur kadar glukosa darah acaknya saat bekerja pada shift pagi dan malam, serta tidak menderita diabetes melitus atau hipertensi, dengan jumlah 26 responden. Hasil penelitian menunjukkan bahwa pola shift kerja yang diterapkan di PT.X adalah sistem shift kerja dengan rotasi lambat mingguan dan pola rotasi mundur yakni malam - siang - pagi. Perubahan kadar glukosa darah acak pada sebagian besar responden menunjukkan nilai yang lebih tinggi saat bekerja pada shift malam daripada shift pagi. Berdasarkan hasil penelitian, PT. X disarankan menerapkan pola shift kerja dengan sistem rotasi cepat dan pola rotasi maju (pagi - siang - malam) dan di akhir jadwal shift malam sebaiknya diberi waktu istirahat selama 24 jam serta mengadakan kegiatan olahraga rutin seminggu sekali di lingkungan PT.X.
\end{abstract}

Kata kunci: glukosa darah acak, shift kerja 


\section{PENDAHULUAN}

Perpanjangan jam kerja dan shift kerja biasa diterapkan untuk lebih memanfaatkan sumber daya yang ada, disebabkan karena kebutuhan akan produksi yang terus meningkat dan menuntut adanya penggunaan sumber daya yang optimal serta meningkatkan proses produksi.

Shift kerja atau kerja gilir ialah strategi penjadwalan jam kerja dengan pola tertentu pada suatu kelompok pekerja dengan melakukan pekerjaan dengan porsi yang sama dalam kurun waktu yang berbeda selama 24 jam dan biasanya terdiri dari tiga giliran waktu yaitu pagi, siang, dan malam hari (Levy, 2011).

Menurut Health Safety Executive (2006), perubahan jadwal kegiatan seperti perubahan shift kerja akan mengganggu circadian rhythm seseorang. Dengan terganggunya circadian rhythm pada tubuh pekerja akan menimbulkan terjadinya dampak fisiologis seperti gangguan tidur, kelelahan, gangguan kesehatan seperti gangguan saluran pencernaan, hipertensi, serangan jantung koroner dan diabetes, serta dapat mempengaruhi kehidupan sosial dan keluarga (Health Safety Executive, 2006).

Penelitian Indrasari
menyebutkan bahwa perawat yang bekerja pada shift malam memiliki kadar glukosa darah yang lebih tinggi daripada perawat yang bekerja pada shift pagi. Hal ini disebabkan karena gangguan metabolisme hormonal yang terjadi karena perubahan waktu biologi tubuh yang menyebabkan hormon pengatur nafsu makan menjadi tidak stabil sehingga meningkatkan rasa lapar dan gangguan metabolisme seperti peningkatan resistensi hormon insulin terhadap gula didalam darah yang dapat meningkatkan risiko terjadinya penyakit diabetes tipe 2 (Caruso, 2012).

Menurut penelitian yang dilakukan oleh Kroenke dalam Szosland (2010), terdapat hubungan yang signifikan antara shift kerja dengan terjadinya diabetes melitus tipe 2 berdasarkan studi yang dilakukan pada populasi wanita usia muda sampai menengah. Penelitian Mikuni et al dalam Szosland (2010), juga melaporkan bahwa prevalensi kejadian diabetes melitus banyak dialami oleh pekerja shift (Szosland, 2010).

Diabetes melitus adalah penyakit gangguan metabolisme akibat tubuh tidak mampu memproduksi hormon insulin yang cukup atau tubuh tidak dapat menggunakan hormon insulin secara efektif, akibatnya terjadi peningkatan konsentrasi kadar gula dalam darah.

Penyakit diabetes merupakan penyakit seumur hidup yang dapat mengakibatkan berkurangnya kualitas hidup dan produktivitas seseorang. Hal ini disebabkan karena penyakit diabetes dapat menyebabkan efek komplikasi jangka panjang terhadap fungsi fisik tubuh, seperti gangguan ketajaman penglihatan, gangguan ginjal, penyakit jantung yang baik secara langsung maupun tidak langsung akan membatasi aktivitas fisik penderita diabetes yang menyebabkan berkurangnya produktivitas pada kinerja (Dewi, 2014).

\section{IDF (International Diabetes}

Federation) memperkirakan bahwa terdapat 382 juta orang yang hidup dengan diabetes di seluruh dunia pada tahun 2013. Diperkirakan dari 382 juta orang tersebut, 175 juta diantaranya belum mengetahui bahwa dirinya menderita diabetes, sehingga ditakutkan akan berkembang menjadi penyakit komplikasi tanpa disadari dan tanpa adanya tindakan pencegahan. Pada tahun 2035 jumlah tersebut diperkirakan akan meningkat menjadi 592 juta orang.

Shift kerja, selain memiliki beberapa keuntungan dari segi proses produksi, juga memiliki dampak negatif. Dampak yang ditimbulkan dari shift kerja meliputi dampak fisiologis, sosial dan performansi atau kinerja. Dampak fisiologis yang muncul merupakan reaksi tubuh terhadap kondisi shift sebagai stresor di tempat kerja (Pulat, 2002). Salah satu dampak dari shift kerja adalah pekerja berpotensi untuk mengalami dehidrasi meskipun pekerjaan tersebut dilaksanakan pada pagi hari (Puspita dan Noeroel, 2017)

Dengan adanya shift kerja dan aktivitas kerja yang terus menerus selama 24 jam tersebut akan mempengaruhi fungsi fisiologis dasar tubuh manusia yang berhubungan dengan jam biologis manusia yang memiliki irama dan ritmenya sendiri dan biasa disebut sebagai circadian rhythm (Goestch, 2008).

Circadian rhythm berhubungan dengan suhu tubuh, tingkat metabolisme, denyut nadi, tekanan darah, dan komposisi kimia tertentu pada tubuh. Denyut nadi, tekanan darah dan suhu tubuh akan meningkat pada siang hari, dan akan menurun pada malam hari, karena itulah mengapa kita merasa lelah dan mengantuk pada malam hari. Karena adanya siklus inilah alasan mengapa kita selalu melakukan rutinitas yang sama untuk makan dan tidur setiap harinya. 
Circadian rhythm dipengaruhi oleh faktor lingkungan seperti terang, gelap dan suhu lingkungan (Health Safety Executive, 2006).

Risiko tersebut juga dapat terjadi pada pekerja di unit bagian produksi Rolling mill PT. $X$. Sebagai sebuah pabrik penghasil baja, dalam mengoptimalkan proses produksinya, PT. X juga memberlakukan kerja shift bagi para pekerjanya, terutama pada pekerja di unit bagian produksi Rolling mill. Di PT. X sendiri belum pernah diadakan penelitian khusus mengenai efek yang ditimbulkan dari shift kerja, baik yang dilakukan oleh manajemen PT. $\mathrm{X}$ maupun oleh pihak lain. Bahkan pekerja di PT. X juga belum pernah diberi penyuluhan baik tentang dampak yang ditimbulkan oleh shift kerja, maupun penyuluhan tentang penyakit diabetes. Hal tersebut memunculkan keinginan peneliti untuk menganalisis kadar glukosa darah pada pekerja shift pagi dan shift malam di unit produksi Rolling mill PT. X.

\section{METODE}

Jenis ini adalah penelitian crossectional observasional yang kemudian diolah secara deskriptif yang bertujuan untuk melihat gambaran suatu kejadian yang terjadi di dalam suatu populasi tertentu (Notoatmojo, 2010).

Populasi dalam penelitian ini merupakan pekerja di unit produksi Rolling mill yang bekerja dengan sistem kerja shift dan bekerja shift pagi pada tanggal dilaksanakannya penelitian yang diukur kadar glukosa darah acaknya, dan kemudian diukur kembali pada saat pekerja yang sama bekerja pada shift malam dengan jumlah 28 orang.

Teknik pengambilan sampel dalam penelitian ini menggunakan total sampling yang memenuhi kriteria inklusi yaitu bersedia dengan sukarela menjadi responden dalam penelitian serta tidak sedang menderita penyakit diabetes melitus atau hipertensi. Dari kriteria yang ditetapkan maka didapatkan jumlah sampel sebanyak 26 orang.

Kriteria eksklusi dalam penelitian ini yaitu tidak bersedia atau menolak untuk menjadi responden dalam penelitian dan memiliki penyakit diabetes atau hipertensi. Terdapat 2 orang yang dieksklusi dari penelitian ini yang disebabkan karena menderita hipertensi.

Penelitian ini bertempat di PT.X yang merupakan sebuah pabrik peleburan baja dan berlokasi di Sepanjang, Sidoarjo. Penelitian ini dilakukan pada bulan September 2015. Variabel yang diteliti dalam penelitian ini adalah pola shift kerja, dan kadar glukosa darah acak.

Data yang dikumpulkan dalam penelitian ini adalah data primer dan data sekunder. Data primer diperoleh melalui pengisian kuesioner oleh responden mengenai shift kerja dan upaya pengendalian efek yang diakibatkan oleh shift kerja di PT.X serta melalui pengukuran kadar glukosa darah acak.

Pengukuran kadar glukosa darah acak dengan teknik pengambilan darah kapiler dengan menggunakan alat glucose stick test dengan merk Easy Touch, dilakukan dengan tahapan sebagai berikut, yakni pertama nyalakan alat dan masukkan chip kalibrasi dari alat, kemudian tunggu hingga alat menyala dan menunjukkan angka yang sama dengan angka yang terdapat pada chip kalibrasi, jika angka yang ditunjukkan sama, maka alat siap untuk digunakan dan telah dikalibrasi. Langkah selanjutnya masukkan strip glukosa pada alat pengukur Easy Touch, lalu jari yang akan ditusuk, dibersihkan dengan alkohol swab dan kemudian dipegang dan ditekan sedikit agar rasa nyeri berkurang dan kemudian jari ditusuk dengan cepat menggunakan lancet steril. Tetes darah pertama yang keluar diusap dengan kapas kering steril. Tetes darah berikutnya dipakai untuk pemeriksaan. Darah diteteskan diatas area tes pada tes strip glukosa hingga menutupi area tes, lalu luka ditutup dengan kapas steril. Tunggu hingga hasilnya muncul pada layar dan catat hasil yang muncul.

Data sekunder diperoleh dengan cara mencatat data yang ada di perusahaan tentang gambaran umum perusahaan, profil perusahaan, jumlah pekerja, jadwal shift kerja, dan catatan riwayat kesehatan pekerja. Data hasil pengisian kuesioner dan pengukuran kadar glukosa darah acak yang telah dilakukan di lokasi penelitian, kemudian diolah secara manual dan disajikan dalam bentuk tabel untuk selanjutnya dianalisa secara deskriptif.

Data mengenai kadar glukosa dan tekanan darah pada pekerja di unit bagian produksi Rolling mill PT. X selanjutnya dianalisis dengan menggunakan analisis deskriptif berupa nilai persentase, nilai maksimal, nilai minimal, dan nilai rata-rata dengan mengggunakan bantuan komputer. Untuk mengetahui perubahan kadar glukosa dan tekanan darah responden unit bagian produksi Rolling mill PT. X pada shift pagi dan malam, dilihat berdasarkan nilai persentase kenaikan atau penurunan yang dihasilkan dari 
hasil pengukuran dan analisis deskriptif dari data tersebut.

\section{HASIL}

\section{Karakteristik Responden}

Tabel 1. Distribusi Frekuensi Umur Responden Unit Bagian Produksi Rolling mill PT. X Tahun 2015

\begin{tabular}{|c|c|c|}
\hline Umur & \multicolumn{2}{|c|}{ Jumlah } \\
\cline { 2 - 3 } (Tahun) & n & $\mathbf{( \% )}$ \\
\hline $23-27$ & 5 & 19 \\
$28-32$ & 4 & 15 \\
$33-37$ & 5 & 19 \\
$38-42$ & 2 & 8 \\
$43-47$ & 7 & 27 \\
$48-53$ & 3 & 12 \\
\hline Total & 26 & 100 \\
\hline
\end{tabular}

Tabel 1 menunjukkan bahwa distribusi frekuensi umur responden unit bagian produksi Rolling mill PT. X yang paling banyak terdapat pada kelompok umur $43-47$ th dengan total 7 orang dari 26 responden dan memiliki persentase sebesar $27 \%$. Untuk kelompok umur esponden yang paling sedikit terdapat pada kelompok umur $38-42$ tahun dengan jumlah 2 orang responden dari total 26 responden. Umur
Distribusi frekuensi umur responden dapat dilihat pada tabel 1 di bawah ini.

Tabel 2. Distribusi Masa Kerja Responden Unit Bagian Produksi Rolling mill PT. X Tahun 2015.

\begin{tabular}{|c|c|c|}
\hline \multirow{2}{*}{$\begin{array}{c}\text { Masa Kerja } \\
\text { (Tahun) }\end{array}$} & n & Jumlah \\
\cline { 2 - 3 } & 8 & 31 \\
$6-5$ & 5 & 19 \\
$12-17$ & 5 & 19 \\
$18-23$ & 4 & 15 \\
$24-29$ & 3 & 12 \\
$30-34$ & 1 & 4 \\
\hline Total & 26 & 100 \\
\hline
\end{tabular}

Distribusi masa kerja responden menunjukkan bahwa kelompok responden yang paling banyak ialah kelompok responden dengan masa kerja $0-5$ tahun yakni sebanyak 8 orang dari total 26 responden dengan presentase sebesar $31 \%$. Kemudian untuk masa kerja yang paling rendah ialah kelompok masa kerja 30 - 34 tahun dengan jumlah hanya 1 orang dari total 26 responden. Masa kerja yang paling tinggi yakni 33 tahun, sedangkan untuk masa kerja yang paling rendah yakni 2 bulan.

\section{Pola Shift Kerja di PT.X}

Pekerja di unit produksi Rolling mill terdiri dari 2 jenis pekerja yakni pekerja yang melakukan sistem kerja shift dan pekerja yang tidak melakukan sistem kerja shift. responden yang paling tinggi yakni 53 tahun dan umur responden yang paling rendah ialah 23 tahun.Jenis kelamin responden unit bagian produksi Rolling mill PT. X semuanya berjenis kelamin laki-laki dan berjumlah 26 orang.

Data distribusi masa kerja responden selengkapnya dapat dilihat pada tabel 2 dibawah ini: 
backward rotation yang dimulai dari shift malam, siang kemudian pagi.

Pekerja yang bekerja dengan sistem kerja shift mempunyai waktu istirahat selama 1 hari dalam 1 minggu yang bisa diambil secara bergantian dan acak, hal ini menyebabkan hari libur pekerja yang tidak menentu.

\section{Kadar Glukosa Darah Acak pada Pekerja Shift Pagi dan Shift Malam}

Berdasarkan hasil pengukuran kadar glukosa darah acak pada pekerja shift pagi dan shift malam di unit produksi Rolling mill PT. X diperoleh hasil bahwa nilai rata-rata kadar glukosa darah acak responden pada shift malam ialah $119,73 \mathrm{mg} / \mathrm{dl}$. Kadar glukosa darah pekerja saat shift pagi yakni 117, $19 \mathrm{mg} / \mathrm{dl}$. Nilai maksimum kadar glukosa darah acak responden yang tertinggi terdapat pada saat responden bekerja shift malam yakni $144 \mathrm{mg} / \mathrm{dl}$ dimana nilai tersebut meskipun melebihi nilai rujukan glukosa darah untuk pemeriksaan glukosa darah acak masih menunjukkan nilai yang normal.

Untuk perubahan kadar glukosa darah acak terbesar yakni sebesar $19 \mathrm{mg} / \mathrm{dl}$. Sedangkan untuk nilai minimum kadar glukosa acak responden yang terendah terdapat pada shift pagi dengan nilai sebesar $90 \mathrm{mg} / \mathrm{dl}$, dan untuk nilai perubahan kadar glukosa darah acak minimal yang terjadi sebesar $1 \mathrm{mg} / \mathrm{dl}$.

Distribusi data perubahan kadar glukosa darah acak pada responden selengkapnya dapat dilihat pada tabel 3 dibawah ini:

Tabel 3. Distribusi Perubahan Kadar Glukosa Darah Acak pada Responden Unit Bagian Produksi Rolling mill PT. X Tahun 2015

\begin{tabular}{|c|c|c|}
\hline Perubahan Kadar Glukosa Darah & \multicolumn{2}{|c|}{ Jumlah } \\
\cline { 2 - 3 } Acak & n & $(\boldsymbol{\%})$ \\
\hline Naik & 20 & 77 \\
Turun & 6 & 23 \\
Tetap & 0 & 0 \\
\hline Total & 26 & 100 \\
\hline
\end{tabular}

Data pengukuran kadar glukosa darah acak responden di unit produksi Rolling mill PT. X menunjukkan bahwa semua responden yang diukur kadar glukosa darah acaknya mengalami perubahan. Perubahan yang paling banyak terjadi ialah kadar gukosa darah acak yang mengalami kenaikan pada saat responden bekerja shift malam dibandingkan dengan pekerja pada shift pagi yaitu sebesar $77 \%$ dan jumlah 20 responden dari total 26 responden. Hanya 6 orang responden saja yang mengalami penurunan kadar glukosa darah acak pada saat bekerja shift malam daripada shift pagi dengan persentase $23 \%$ dari total 26 responden.

\section{PEMBAHASAN \\ Shift Kerja}

Menurut Levy (2011), shift kerja atau kerja gilir ialah salah satu cara dalam mengatur penjadwalan waktu kerja sehingga pekerja dapat melakukan pekerjaan yang sama pada waktu yang bebeda selama periode waktu 24 jam, biasanya terdiri dari tiga giliran waktu yaitu pagi, siang, dan malam hari.

Shift kerja pada umumnya diterapkan untuk lebih memanfaatkan sumber daya yang ada, meningkatkan produktivitas, serta memperpanjang durasi pelayanan. Shift kerja berbeda dengan hari kerja biasa karena dapat dilakukan lebih dari satu kali untuk memenuhi jadwal 24 jam per hari.

Pengaturan jam kerja dalam sistem shift diatur dalam Undang-Undang No. 13 Tahun 2003 mengenai Ketenagakerjaan salah satunya yang terdapat dalam pasal 77 ayat 2 mengenai jam kerja di lingkungan suatu perusahaan atau badan hukum lainnya (perusahaan) ditentukan selama 8 jam per hari dan jumlah jam kerja tidak boleh lebih dari 40 jam per minggu (Presiden Republik Indonesia, 2003).

Undang-Undang Republik Indonesia No 13 Tahun 2003 Pasal 78 juga menyebutkan bahwa setiap pekerja yang bekerja melebihi ketentuan waktu kerja 8 jam per hari atau melebihi jumlah jam kerja akumulatif 40 jam per minggu, harus ada perintah tertulis dari perusahaan dan persetujuan tertulis dengan pekerja yang bersangkutan serta wajib mendapat upah kerja lembur (Presiden Republik Indonesia, 2003).

Menurut Undang-Undang Republik Indonesia No. 13 Tahun 2003 mengenai Ketenagakerjaan, pembagian jam kerja untuk tiap shift sudah sesuai yakni 8 jam per hari, termasuk istirahat antar jam kerja dan jumlah jam kerja secara akumulatif masing-masing 
shift tidak lebih dari 40 jam per minggu. Jam kerja shift pagi yang dimulai jam 7 pagi dinilai sudah cukup ideal menurut Caruso, karena jam kerja yang tidak terlalu pagi dapat membuat pekerja memiliki kualitas tidur yang baik dan memiliki cukup waktu untuk persiapan bekerja (Presiden Republik Indonesia, 2003).

Menurut Levy (2011), berdasarkan polanya, shift kerja dibagi menjadi tiga macam yakni Shift kerja rotasi (rotation) dan shift kerja permanen (permanent). Shift kerja permanen adalah tenaga kerja yang bekerja dengan shift yang tetap setiap harinya. Tenaga kerja yang bekerja pada shift malam adalah orang yang bersedia bekerja pada malam hari dan tidur pada siang hari. Shift kerja rotasi adalah pekerja yang bekerja dengan waktu kerja yang dibagi secara bergilir dalam waktu 24 jam. Pekerja yang terlibat dalam sistem rotasi ini akan berubah-ubah waktu kerjanya yakni pagi, sore maupun malam.

Pola shift Forward or backward rotation. Forward rotation adalah pergantian shift kerja yang dimulai dari shift pagi, siang kemudian shift malam. Backward rotation adalah pergantian shift kerja yang dimulai dari shift malam, siang kemudian pagi.

Fast or slow rotation. Fast rotation shift work adalah pola pergantian kerja shift secara cepat, yakni jadwal pergantiannya hanya berselang dalam hitungan hari, baik 1 hari, 2 hari atau 3 hari sekali pergantian. Sedangkan slow rotation adalah pola pergantian shift secara lambat yang biasanya pola pergantian shiftnya berlangsung setiap bulan atau minggu, misalnya seminggu shift malam, seminggu shift sore atau seminggu shift pagi.

Menurut Levy (2011), pola shift kerja yang diberlakukan di PT. X termasuk dalam pola sistem kerja rotasi lambat mingguan yakni sistem shift yang dilakukan pergantian shift selama seminggu sekali. Pergantian jadwal shift dalam waktu seminggu sekali ini diterapkan dengan alasan untuk memudahkan kepala departemen dalam membuat jadwal shift daripada membuat jadwal shift dengan rotasi cepat, namun kepala departemen cukup terbuka untuk melakukan penjadwalan shift kerja, dimana para pekerja dapat request kapan dia akan libur asalkan ada yang menggantikan posisinya.

PT. X juga menerapkan pola rotasi mundur atau backward rotation yang dimulai dari shift malam - siang - pagi. Alasan menggunakan pola ini yakni agar pekerja memiliki waktu yang lebih banyak untuk istirahat pada saat sesudah bekerja pada shift malam menuju ke shift siang daripada menggunakan sistem rotasi maju dimana pekerja tidak memiliki waktu istirahat apabila setelah bekerja shift malam langsung dilanjut dengan shift pagi. Karena terkadang setelah bekerja pada shift malam pekerja tidak memiliki hari libur di akhir jadwal shift disebabkan jatah hari liburnya telah diambil pada hari yang lain.

Kerja shift dapat menimbulkan beberapa efek pada tubuh manusia diantaranya yaitu efek fisiologis, efek sosial, dan efek kinerja. Efek fisiologis yang ditimbulkan oleh shift kerja diantaranya seperti berkurangnya kemamupuan fisik dan mental, mempengaruhi kualitas tidur, gangguan saluran pencernaan, gangguan sistem kardiovaskular dan gangguan sistem metabolisme hormonal (Pulat, 2002).

Efek sosial yang ditimbulkan oleh shift kerja diantaranya kurangnya interaksi dengan keluarga, kerabat dan rekan. Terutama pada pekerja shift malam. Dimana waktu yang biasa digunakan untuk berinteraksi dengan masyarakat sekitar yakni pagi atau sore hari dipergunakan untuk beristirahat. Karena itu pola shift kerja rotasi lambat kurang baik untuk diterapkan.

Kondisi kerja shift malam juga dapat mempengaruhi perilaku kewaspadaan pekerjaan seperti kualitas kendali dan pemantauan yang berakibat pada kinerja termasuk tingkat kesalahan, ketelitian dalam melakukan pekerjaannya, dan tingkat kecelakaan, akan lebih tinggi di malam hari dibandingkan pada siang hari. Karenanya pola shift kerja rotasi lambat sebaiknya dihindari agar terhindar dari terjadinya kelelahan kronis (Levy, 2011).

Terdapat 3 model sistem shift kerja diantaranya model ILO (2003), normal 8jam per shift. Pekerja yang melakukan Shift yang dalam waktu 24 jam termasuk hari minggu dan hari libur perlu membentuk 4 regu kerja. Regu kerja tersebut dikenal dengan regu kerja terusmenerus (3x8) (Pulat, 2002).

Model 2-2-2 yang biasa diterapkan di Inggris. Sistem ini disebut dengan sistem rotasi pendek. Dimana lama tiap shift terdiri dari 2 hari kerja dan pada akhir shift diberikan libur selama 2 hari (Pulat, 2002).

Model 2-2-3 merupakan sistem rotasi pendek. Dimana salah satu shift dilaksanan dalam 3 hari kemudian 2 ahift lainnya dilaksanakan selama 2 hari dan pada akhir 
periode shift diberikan waktu libur 2 hari. Siklus ini dilakukan bergantian untuk setiap shift. Pada akhir shift malam diperlukan istirahat minimal selama 24 jam. Sistem rotasi ini dianjurkan oleh para ahli, dengan mempertimbangkan faktor sosial dan psikologis (Pulat, 2002).

Sistem rotasi kerja shift yang terbaik dan banyak direkomendasikan oleh para ahli ialah pola shift dengan model rotasi cepat 2-2-3. Dimana salah satu shift dilaksanakan dalam 3 hari kemudian 2 shift lainnya dilaksanakan selama 2 hari dan pada akhir periode shift diberikan waktu libur 2 hari (Pulat, 2002).

Rotasi shift kerja secara cepat yakni setiap 2 atau 3 hari menurut penelitian Indrasari (2011), dapat mengurangi gangguan pada jam biologis seseorang dibandingkan dengan shift kerja rotasi lambat mingguan. Seseorang yang mengalami pergantian shift, membutuhkan waktu penyesuaian agar irama sirkadiannya berubah mengikuti irama kerjanya, namun tentu saja tidak mungkin untuk melakukan adaptasi $100 \%$. Oleh karena itu pola sistem rotasi ini banyak direkomendasikan oleh para ahli, terutama dengan pertimbangan dari faktor fisiologis, sosial dan psikologis (Pulat, 2002).

Pola rotasi shift yang terbaik ialah menggunakan rotasi maju yakni pola shift yang dimulai dari shift pagi - siang - malam. Dan pada akhir shift malam diperlukan istirahat minimal selama 24 jam sebelum dilanjutkan dengan shift yang selanjutnya (Pulat, 2002).

Menurut Maurits dan Widodo (2008) pada penelitian mengenai faktor dan penjadwalan shift kerja terdapat beberapa poin yang perlu diperhatikan dalam penyusunan shift kerja, diantaranya yaitu waktu pergantian shift kerja sebaiknya dengan pola rotasi maju yakni dimulai dari shift pagi - siang - malam dan waktu rotasi cepat yakni waktu rotasi yang berganti setiap beberapa hari sekali dengan waktu libur rata-rata 2 hari/minggu.

Durasi shift kerja sebaiknya tidak boleh melebihi dari 8 jam, jika melebihi maka beban kerja sebaiknya dikurangi. Pada pekerja shift malam dianjurkan agar beristirahat atau tidur siang terlebih dahulu sebelum bekerja dan mengerjakan pekerjaan sebelum jam 4 pagi karena setelah jam 4 pagi, terjadi beberapa perubahan pada tubuh yang diakibatkan karena circadian rhythm diantaranya seperti perubahan pada sekresi hormon cortisol, suhu badan dan tingkat melatonin yang dapat berpengaruh pada kinerja pekerja. Melakukan time out pada saat melakukan shift malam seperti tidur sebentar atau istirahat dengan duduk dapat menimbulkan efek positif untuk mengurangi kelelahan. Aspek demografis seperti jenis kelamin dan umur perlu diperhatikan dalam penyusunan shift kerja.

\section{Glukosa Darah dan Kerja Shift}

Terdapat 3 kategori klasifikasi kadar gula darah yakni kadar gula darah tinggi (hiperglikemia), prediabetes, dan kadar gula darah rendah (hipoglikemi). Kadar gula darah yang melebihi dari nilai normal disebut dengan hiperglikemia, apabila kadar gula darah dalam tubuh terus meningkat maka hal ini akan berpotensi menimbulkan diabetes melitus atau kencing manis. Penyakit diabetes melitus dapat didiagnosis dengan salah satu dari kriteria yaitu gula darah sewaktu > $200 \mathrm{mg} / \mathrm{dl}$, gula darah puasa $>120 \mathrm{mg} / \mathrm{dl}$, tes $\mathrm{HbAlC} \geq 6,5 \%$ (HbA1C adalah tes darah yang memberikan gambaran kadar gula darah rata-rata dalam 3 bulan terakhir), dan tes gula dua jam setelah makan (post prandial) > $200 \mathrm{mg} / \mathrm{dl}$. Diagnosis diabetes melitus tidak hanya dilihat berdasarkan kriteria tersebut, namun juga bisa ditegakkan berdasarkan pertimbangan gejala klinis, sehingga perlu pemeriksaan lebih lanjut oleh dokter.

Kategori Prediabetes merupakan kondisi dimana seseorang berisiko tinggi terkena penyakit diabetes. Hal ini dapat dicegah agar tidak menjadi diabetes dengan melakukan pola hidup yang sehat yaitu meningkatkan aktivitas fisik, mengonsumsi makanan yang sehat, dan mengontrol berat badan. Kategori kadar gula darah rendah (hipoglikemia) terjadi ketika kadar gula darah berada dibawah normal, yaitu kurang dari $70 \mathrm{mg} / \mathrm{dl}$. Nilai rujukan dari kadar gukosa darah acak sebagai patokan dalam uji saring dan diagnosis diabetes melitus untuk orang dewasa yakni $\leq 140 \mathrm{mg} / \mathrm{dl}$.

Kadar glukosa darah yang diukur pada responden di unit produksi Rolling mill PT. X merupakan kadar glukosa darah acak. Dengan alasan agar tidak menambah beban kerja responden pada saat bekerja terutama pada saat bekerja shift malam dan tidak mengganggu pekerjaannya. Untuk meminimalisasi faktor pengganggu pada pengukuran kadar glukosa darah acak, waktu pengukuran kadar glukosa darah acak dilakukan sebelum jam makan. Untuk shift pagi, pengukuran dilakukan pada pukul 10.00 sebelum jam istirahat makan siang dan pada shift malam pengukuran dilakukan 
pada pukul 06.00 sebelum pekerja pulang kerumah dan makan pagi.

Kadar glukosa darah acak yang diukur pada pekerja di unit produksi Rolling mill PT. $\mathrm{X}$, pada sebagian besar pekerja menunjukkan adanya kenaikan ketika bekerja pada shift malam daripada bekerja pada shift pagi yaitu sebesar $77 \%$ dan jumlah 20 responden dari total 26 responden. Seperti yang dinyatakan oleh Indrasari (2011), pada penelitiannya mengenai kadar glukosa darah pada perawat yang bekerja shift pagi dan malam dimana perawat yang bekerja shift malam memiliki kadar glukosa darah yang lebih tinggi daripada perawat yang bekerja pada shift pagi.

Caruso (2012), menyatakan bahwa hal ini disebabkan karena gangguan metabolisme hormonal yang terjadi karena perubahan waktu biologi tubuh pada saat bekerja shift malam. Pada malam hari, waktu yang biasa digunakan untuk tidur digunakan untuk bekerja, sehingga menyebabkan terjadinya gangguan pada circadian rhythm dalam tubuh yang menyebabkan hormon pengatur nafsu makan menjadi tidak stabil sehingga meningkatkan rasa lapar dan gangguan metabolisme seperti peningkatan resistensi hormon insulin terhadap gula darah, dan mengurangi toleransi penyerapan lemak dalam tubuh yang dapat meningkatkan risiko terjadinya penyakit diabetes melitus tipe 2 dan obesitas.

Benedict (2012), juga menyebutkan bahwa orang yang mengalami perubahan pola tidur akan mengalami gangguan metabolisme gula dalam tubuhnya. Hal ini terjadi karena adanya peningkatan resistensi insulin terhadap gula didalam darah sebagaimana dibuktikan pada penelitian Buxton et al., (2010) yang meneliti responden laki-laki sehat dan diberi perlakuan berupa perubahan pola tidur selama kurun waktu 1 minggu dan hasilnya menunjukkan adanya penurunan sensitivitas dari hormon insulin.

Menurut penelitian yang dilakukan oleh Kroenke dalam Szosland (2010) menunjukkan bahwa terdapat hubungan antara shift kerja dengan terjadinya diabetes melitus tipe 2 berdasarkan studi yang dilakukan pada populasi wanita usia muda sampai menengah. Penelitian Mikuni et al dalam Szosland (2010), juga melaporkan bahwa prevalensi kejadian diabetes melitus banyak dialami oleh pekerja shift daripada pekerja non shift.

Menurut Doghramji (2007), Circadian rhythm merupakan dasar fisiologis dan psikologis pada siklus tidur dan bangun seharihari, karena kerja circadian rhythm ini dipengaruhi oleh cahaya matahari, dimana cahaya matahari akan mempengaruhi retina yang kemudian akan memberikan sinyal kepada saraf ke optic SCN (Suprachiasmatic Nucleus). SCN adalah bagian dari hipotalamus yang berperan untuk mempengaruhi fungsi pengaturan tidur, temperatur suhu tubuh, sekresi hormon, produksi urin dan tekanan darah irama tubuh dalam sehari.

Menurut Starr (2014), adanya gangguan pada circadian rhythm ini direspon tubuh sebagai stressor yang berpengaruh pada regulasi homon kortisol. Hormon kortisol memiliki efek pada metabolisme pembentukan glukosa (glukoneogenesis) terutama di dalam hati. Hormon ini merangsang meningkatnya pembentukan glukosa dari molekul seperti lemak dan protein yang tidak mengandung karbohidrat oleh hati, dan akan menghambat penggunaan glukosa oleh sel sehingga kadar glukosa dalam darah cenderung naik.

Hormon kortisol memiliki dampak positif dan negatif. Dampak positif dari hormon ini adalah lebih memacu seseorang untuk bekerja dan membuatnya untuk menjadi lebih fokus. Dampak negatif dari hormon ini yakni jika diproduksi berlebihan akibat dari stress yang berkepanjangan maka dapat menimbulkan reaksi kelelahan yang pada akhirnya mengakibatkan depresi, dan menyebabkan risiko munculnya penyakit seperti hipertensi, sakit jantung, asma, gastrointestinal, dan diabetes.

Menurut Starr (2014), selain dapat dipengaruhi oleh stress yang diakibatkan karena respon tubuh terhadap stressor, dalam hal ini yakni shift kerja. Kadar glukosa darah juga dapat dipengaruhi oleh hal lain yakni aktivitas fisik. Aktivitas yang dilakukan oleh pekerja pada saat bekerja shift pagi dan shift malam tentunya berbeda. Dimana aktivitas pada pagi hari biasanya lebih banyak daripada di malam hari.

Aktivitas fisik akan meningkatkan transport glukosa kedalam sel yang menyebabkan terjadinya perubahan metabolisme termasuk metabolisme glukosa, sehingga dengan meningkatnya intensitas dan durasi aktivitas akan menyebabkan meningkatnya proses pemecahan glikogen pada hati dan otot menjadi glukosa oleh organ hati, karenanya aktivitas fisik yang kurang, dapat 
menyebabkan peningkatan kadar glukosa dalam darah.

Berdasarkan hasil kuesioner diperoleh informasi bahwa PT. X memberikan fasilitas kepada para pekerjanya berupa kopi pada saat bekerja shift malam. Kebiasaan minum kopi yang dilakukan oleh pekerja shift malam juga dapat berpengaruh pada kenaikan kadar gula darah acak pekerja shift malam, karena kandungan gula yang terdapat dalam kopi dapat meningkatkan kadar gula darah secara drastis.

Menurut Starr (2014), makanan atau diet merupakan faktor utama yang berhubungan dengan peningkatan kadar glukosa darah terutama setelah makan. Peningkatan kadar glukosa biasanya terjadi setelah kita makan atau minum namun hal ini juga dapat terjadi jika insulin yang diproduksi oleh tubuh terlalu sedikit atau tidak dapat berfungsi dengan baik. Keadaan ini biasanya dikenal dengan diabetes mellitus.

\section{Upaya Pengendalian Efek yang Diakibatkan oleh Shift Kerja di PT. X.}

Shift kerja selain memiliki dampak positif juga memiliki dampak negatif yang tidak dapat dihindari. Agar efek negatif yang ditimbulkan oleh shift kerja ini dapat diminimalisir maka diperlukan adanya upaya pengendalian.

Menurut Caruso (2012), strategi dalam menangani efek yang diakibatkan oleh shift kerja lebih difokuskan pada pencegahan dan pengendalian stress ditempat kerja, karena shift kerja bertindak sebagai stressor. Strategi yang dapat dilakukan diantaranya melalui strategi penanganan organisasional, individual dan dukungan sosial.

Upaya pengendalian efek akibat shift kerja yang telah dilakukan di PT.X yakni dengan mengadakan pemeriksaan kesehatan berkala bagi karyawan yang diadakan setiap 1 tahun sekali. Hal ini dapat digunakan sebagai upaya untuk monitoring terhadap kondisi kesehatan pekerja dan tindakan pencegahan terhadap kondisi yang tidak diinginkan, seperti terjadinya kecelakaan kerja dan penyakit akibat kerja.

Kelompok pekerja wanita tidak diikutkan dalam kerja shift, karena kelompok tersebut merupakan kelompok yang memiliki risiko tinggi untuk melakukan kerja shift. Namun untuk kelompok pekerja usia lanjut dan pekerja yang memiliki penyakit seperti diabetes melitus, hipertensi, penderita insomnia tetap diikutkan dalam sistem kerja shift karena keterbatasan tenaga yang ada.

Aspek demografis seperti jenis kelamin dan umur perlu diperhatikan dalam penyusunan shift kerja. Oginska dan Pokorski (2006), menyatakan bahwa perempuan pada umumunya membutuhkan waktu tidur yang lebih lama dibanding dengan laki-laki. Perempuan juga cenderung mudah lelah serta mudah mengalami perubahan mood dan masalah kognitif. Pekerja usia lanjut terutama usia 45 tahun keatas, sebaiknya tidak diikutkan kerja shift malam karena berpengaruh pada kinerja dan kewaspadaan motorik yang menurun.

Menurut Pulat (2002), pada jadwal akhir shift malam sebaiknya diberikan istirahat minimal selama 24 jam. Dan hindari membuat pergantian jadwal shift secara cepat yakni dengan waktu pergantian kurang dari $10-11$ jam antar waktu pergantian dari shift yang satu ke shift yang lain. Karena jadwal pergantian waktu yang terlalu cepat akan menyebabkan pekerja tidak memiliki waktu yang cukup untuk beristirahat dan memulihkan kondisinya.

Salah satu penanganan individual yang dapat dilakukan oleh pekerja shift ialah melakukan kegiatan olahraga secara rutin, namun berdasarkan hasil pengisian kuesioner yang telah diisi oleh responden didapatkan bahwa sebagian besar responden tidak pernah melakukan olahraga secara teratur. PT. X juga tidak pernah mengaadakan olahraga rutin sehingga para pekerjanya kurang melakukan aktivitas fisik, hal ini dapat memicu risiko timbulnya penyakit degeneratif seperti obesitas, diabetes melitus dan hipertensi. Seperti yang telah diungkapkan dalam penelitian Noer dan Laksmi (2014), bahwa pekerja shift memiliki persentase kejadian obesitas yang lebih tinggi pada pekerja shift dibanding pekerja non-shift. Hal ini disebabkan karena perubahan perilaku makan dan kelelahan pada pekerja shift yang cenderung mengkonsumsi makanan atau minuman yang manis dan junk food.

Menurut Lowden, et al dalam Caruso (2012), terdapat beberapa cara diet sebagai strategi penanganan individual yang dapat diterapkan oleh pekerja yang bekerja dengan sistem kerja shift atau pekerja dengan jam kerja yang panjang, diantaranya yakni untuk menghindari atau mengurangi asupan makanan selama tengah malam sampai dengan jam 6 pagi, supaya siklus circadian tidak terganggu. Karena siklus circadian, umumnya organ pencernaan kita bekerja pada pagi hari dan 
istirahat pada malam hari sehingga pekerja shift dianjurkan agar lebih banyak mengonsumsi makanan yang memiliki serat tinggi seperti sayur dan buah, serta makanan yang memiliki kandungan protein tinggi. Selain itu PT. X juga tidak pernah memberikan informasi kepada pekerjanya mengenai dampak yang ditimbulkan dari sistem kerja shift.

\section{KESIMPULAN}

Berdasarkan hasil penelitian, pola shift kerja yang diberlakukan di PT. X termasuk dalam pola sistem kerja rotasi lambat mingguan dan memiliki pola rotasi mundur atau backward rotation yang dimulai dari shift malam, siang kemudian pagi. Pola shift kerja yang diterapkan sebaiknya mengunakan pola sistem rotasi cepat yakni dengan pola 2-2-3 serta menggunakan pola rotasi maju atau forward rotation (pagi siang - malam) dan pada akhir jadwal kerja shift malam sebaiknya diberi waktu istirahat selama 24 jam untuk memulihkan kondisi dan kebugaran pekerja.

Kadar glukosa darah acak yang diukur pada sebagian besar pekerja menunjukkan adanya kenaikan ketika bekerja pada shift malam, daripada saat bekerja pada shift pagi, oleh karena itu sebaiknya diadakan kegiatan olahraga rutin setiap seminggu sekali di lingkungan PT.X dan diberikan penyuluhan terkait dengan dampak negatif dari shift kerja.

\section{DAFTAR PUSTAKA}

Benedict. 2012. Diurnal Rhythym of Circulating Nicotinamide Phosphoribosyltranferase: Impact of Sleep Loss and Relation to Glucose Metabolism. J Clin Endocrin Metabolic, 97(2), pp. 218222.

Buxton, O. M. et al. 2010. Sleep restriction for 1 week reduces insulin sensitivity in healthy men. Journal of the American Dental Association, 59(1), pp. 26-33. doi: 10.2337/db09-0699.

Caruso, C. 2012. Shift Work and Long Work Hours. Occupational Ergonomics. doi: 10.1201/b11717-19.

Dewi, R. 2014. Diabetes Bukan Untuk Ditakuti. Tetap Sehat dengan Pengaturan Pola Makan bagi Penderita Diabetes Tipe 2. Jakarta: FMedia.
Doghramji, K. 2007. Melatonin and its receptors: A new class of sleep-promoting agents. Journal of Clinical Sleep Medicine.

Goestch, D. L. 2008. Occupational Safety and Health. New Jersey. Pearson Education.

Health Safety Executive. 2006. Managing shiftwork - Health and safety guidance. HSE books.

ILO. 2003. Encyclopedia of Occupational Health and Safety. Geneva.

Indrasari, R. 2011. Perubahan Kadar Glukosa Darah Perawat RSI Darus Syifa' Surabaya pada Shift Pagi dan Malam. Tesis. Surabaya: Fakultas Kesehatan Masyarakat. Universitas Airlangga.

Levy, B. S. 2011. Occupational and Environmental Health: Recognizing and Preventing. London: Oxford University Press.

Maurits, L.S dan Widodo, I. 2008. Faktor dan Penjadwalan Shift Kerja. Jurnal Teknoin, 13(2), pp. 11-22.

Noer, E.R dan Laksmi, K. 2014. Peningkatan Angka Kejadian Obesitas dan Hipertensi pada Pekerja Shift. Journal of Nutrition and Health, 2(1).

Notoatmojo, S. 2010. Metodologi Penelitian Kesehatan. Jakarta: Rineka Cipta.

Oginska, H. dan Pokorski, J. 2006. Fatigue and mood correlates of sleep length in three age-social groups: School children, students, and employees. Chronobiology International, 23(6), pp. 1317 - 1328. doi: $10.1080 / 07420520601089349$.

Presiden Republik Indonesia. 2003. UndangUndang No.13 Tahun 2003 tentang Ketenagakerjaan.

Pulat, M. B. 2002. The Fundamental Ergonomics. New Jersey: Prentice Hall Engelwood Cliffs.

Puspita, A. D. dan N. W. 2017. Gambaran Iklim Kerja Dan Tingkat Dehidrasi Pekerja Shift Pagi Di Bagian Injection Moulding 1 Pt.X Sidoarjo. Journal of Public Health Research and Community Health Development, 1(1), pp. 15-26.

Starr, C. dan B. M. 2014. Human Biology. Tenth Edition. Cencage Learning. Canada.

Szosland, D. 2010. Shift Work and Metabolic Syndrome, Diabetes Melitus and Ischaemic Heart Disease. International Journal of Occupational Medicine and Environmental Health, 23(3), pp. 287-291. 